\title{
Research on Managerial Entrenchment and Company Capital Structure
}

\author{
Xue-Xia XU ${ }^{a}$, An-Qi LIU ${ }^{b^{\star}}$, Yu-Hui GU ${ }^{c}$, Sun-Lei YANG ${ }^{d}$ \\ Wuhan Textile University, No. 1, Yangguang Road, Jiangxia District, Wuhan, China

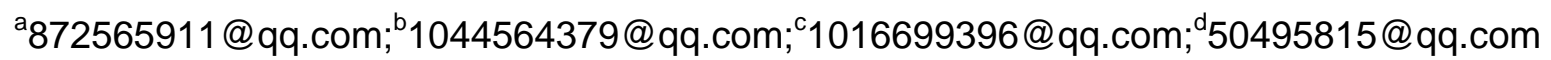

Key words: Managerial entrenchment, Manager's own characteristics, Incentives for managers, Capital structure.

\begin{abstract}
Under the modern enterprise system, it is an inevitable problem for the management to act according to their own interests when making decisions. Therefore, the attitude of management in making decisions will inevitably affect the proportional relationship in the capital structure of the company. In this paper, the characteristics of the manager and the incentive received by the manager two aspects, Based on the relevant data of the main board listed companies from 2014 to 2016, this paper studies the influence of managerial entrenchment on the capital structure of listed companies. Studies have shown that, assuming there is no external threat, the degree of regulatory defense affects the company's capital structure. That is, the higher the level of managerial entrenchment, the more likely the company is to have a low level of debt.
\end{abstract}

\section{Foreword}

Managerial entrenchment refers to the behavior that managers choose to maintain their positions and pursue their own utility maximization under the internal and external control mechanism of the company. The choice of financing mode and debt-equity ratio is the core of capital structure decision. At the same time, how to solve the problem of agency conflict between shareholders and managers is one of the important contents of corporate governance research. In the case of asymmetric information and incomplete contracts, there is a conflict of interest between self-interested managers and shareholders. Shareholders want to make full use of the leverage of debt to maximize income, and managers to reduce the performance pressure to pay interest, in order to reduce the financial distress in order to reduce the huge cost of conversion work (Glson,1989). However, equity financing is preferred and debt financing is avoided as far as possible, thus different financing modes are combined and different capital structures are formed.

At present, the relationship between the managerial entrenchment and the corporate capital structure is mainly based on the manager ' s preference, the incentive and the enterprise debt level . Managers' preference is to study the influence of managers' own characteristics on management defense. AylaKayhanan(2003). From the perspective of managerial entrenchment, it is analyzed that managers' personal preference and motivation will affect the financing behavior of the company. It is concluded that highly defensive managers lack incentives to borrow[1].Fama(1980) also raised this point. Novaes and Zingalesi(1995) suggest that shareholders and managers have different interests because of their respective pursuits. Therefore, the choice of capital structure will be different. Shareholders pursue the maximization of shareholder wealth, while managers pursue the maximization of their own interests[2]. Jensen studies the same problem based on the theory of enterprise equity structure and puts forward similar conclusions.

The relationship between the incentive of managers and the capital structure of the company, Huang Guoliang (2010) puts forward the incentive policy and supervision mechanism of the managers themselves, and analyzes the relationship between managerial entrenchment and capital structure[3]. Later, Li Bingxiang (2017) suggested that incentive 
intensity, incentive duration, performance conditions and managerial entrenchment are negatively correlated[4]. In the relationship between managerial entrenchment level and enterprise debt level, Huang Guoliang pointed out that the stronger the managerial entrenchment level, the lower the liability of managers[5]. Based on the cash flow hypothesis, Jensen(1993) suggests that debt financing can effectively reduce agency problems between owners and managers[6].Zweibel(1996) also argued that shareholders are using debt as a tool to increase the value of the company, but managers use debt as a defensive strategy[7].

The domestic and foreign literature mainly studies the relationship between the external factors, such as incentive and so on. Therefore, this paper mainly from the internal factors, from the manager's own characteristics and incentives to study the impact of managerial entrenchment on the company's capital structure.

\section{Research Hypothesis}

The manager's own characteristics refer to the internal causes of managerial entrenchment behavior, generally speaking, including the age of managers, the qualifications of managers, and the duration of managers. First, according to a study by Eaton and Rosen, the age of managers reflects whether managers' attitudes to risk are conservative or radical[8]. The influence of different age groups on the degree of managerial entrenchment is different . Enterprise identity education has a great influence on people. The degree of individual education can be used as an effective index to judge individual difference. The higher the degree of education, the higher the degree of defense. Finally, Allen and Panian(1982) found a significant positive correlation between tenure and management authority[9].If the term of office is too short, it may affect the inculcation and implementation of the management concept of the manager, which leads to the lower defense level; if the term is too long, the board of directors may not be independent enough, and the defense level will be higher for the manager to pursue his own interests.

Therefore, this study selects the managers' age, education and tenure as the measurement variables from the managers' own characteristics, and the managers' own characteristics are proportional to the managerial entrenchment. We make the following hypotheses:

Hypothesis 1a: To limit other conditions, the older the manager, the higher the level of defense and the lower the level of indebtedness.

Hypothesis 1b: Limited to other conditions, the higher the level of education, the higher the level of defense, the lower the level of debt.

Hypothesis 1c: To limit other conditions, the longer the tenure of the manager, the higher the level of defense and the lower the level of indebtedness

Whether the meaning of shareholders and managers is the same is mainly reflected in the implementation of incentive plan. Reasonable and effective use of equity incentive will make the enterprise develop rapidly, but can not use the equity incentive reasonably, the reverse incentive will also make the enterprise into a dilemma. Friend and Lang (1988) believe that the proportion of debt in the corporate capital structure will decrease with the increase in the share of managers[10].Therefore, the higher the proportion of managers holding shares, the greater the degree of exercise of control over the company, which will lead to a lower degree of defense. Performance incentives may lead to short-term behavior. The improper behavior that managers want to maximize their own interests. The higher the performance incentive, the more willing the management is to seek the best interests, and the lower the corresponding managerial entrenchment. So we make the following hypotheses:

Hypothesis2a: The higher the degree of equity incentive, the lower the degree of managerial entrenchment and the higher the level of debt.

Hypothesis 2b: The higher the managers' performance incentives, the lower the managerial entrenchment and the higher the level of debt. 


\section{Research Design}

\section{Model and Variable Definition}

In this study, 5 variables are used to describe the definition of explanatory variables, and asset liability ratio is used to measure the change of capital structure of explanatory variables. Based on the results of previous studies and the actual situation of listed companies in China, this study selects factors such as company size, liquidity and growth as controlling variables, as shown in Table 1.

Table 1: variable name, Symbol and its definition

\begin{tabular}{|c|c|c|c|}
\hline $\begin{array}{l}\text { Variable } \\
\text { relationship }\end{array}$ & $\begin{array}{l}\text { Variable } \\
\text { name }\end{array}$ & $\begin{array}{l}\text { Variable } \\
\text { symbol }\end{array}$ & Variable-definition \\
\hline $\begin{array}{l}\text { Explained } \\
\text { variable }\end{array}$ & $\begin{array}{l}\text { corporate } \\
\text { capital structure }\end{array}$ & $\mathrm{CS}$ & Asset-liability ratio $=$ Totalliabilities/Total assets \\
\hline \multirow{5}{*}{$\begin{array}{l}\text { Explanatory } \\
\text { variable }\end{array}$} & manager 's age & Age & The actual age of the manager \\
\hline & $\begin{array}{l}\text { Manager } \\
\text { education }\end{array}$ & EB & $\begin{array}{l}\text { 1= Secondary and secondary school, } 2= \\
\text { College, } 3=\text { Undergraduate, } 4=\text { Master graduate } \\
\text { student, } 5=\text { PhD student, } 6=\text { other, } 0=\text { unknown }\end{array}$ \\
\hline & $\begin{array}{l}\text { managerial } \\
\text { tenure }\end{array}$ & TOO & $\begin{array}{l}\text { Length of service of managers disclosed in } \\
\text { company annual reports }(0=\text { Term unknown })\end{array}$ \\
\hline & Equity incentive & EI & managerial ownership \\
\hline & $\begin{array}{l}\text { Performance } \\
\text { incentives }\end{array}$ & $\mathrm{PI}$ & $\begin{array}{l}\text { Bonus and bonus for managers (excl. base } \\
\text { salary) }\end{array}$ \\
\hline \multirow[t]{3}{*}{$\begin{array}{l}\text { Controlled } \\
\text { variable }\end{array}$} & Company Size & SOC & Total company assets end logarithm \\
\hline & Liquidity & $\mathrm{Li}$ & Current ratio= Current assets/ Current liabilities \\
\hline & Growth & Gr & $\begin{array}{l}\text { Total assets growth rate }=(\text { end of the year- the } \\
\text { beginning of the year)/ the beginning of the year }\end{array}$ \\
\hline
\end{tabular}

\section{Sample Selection and Data Sources}

This paper takes the Shanghai main Board listed company as the research sample between December 31 and June 31, 2014. Omitting:(1)Companies listed after January 1st 2013; (2) the particularity of the financial industry;(3)Special processing and incomplete restructuring of ST,* ST,S*ST,PT as well as S companies and companies with incomplete data. The final selection of 832 listed companies, 2035 effective data samples. Data from the Oriental Wealth choice financial terminal, huge tide of information.

\section{The Construction of the Model}

Multiple regression model is used to analyze the relationship between capital structure and managerial entrenchment of listed companies. In order to prove the influence of management and defense on corporate capital structure, a multiple linear regression model is established to verify the following models:

$\mathrm{CS}=\mathrm{X}+\beta 1$ Aget $+\beta 2 \mathrm{EBt}+\beta 3 \mathrm{TOOt}+\beta 4 \mathrm{EIt}+\beta 5 \mathrm{PIt}+\beta 6 \mathrm{SOCt}+\beta 7 \mathrm{Lit}+\beta 8 \mathrm{Grt}+\beta 9 \mathrm{Int}$

Where $\mathrm{X}$ is the constant term and 1-9 is the regression coefficient.

\section{Empirical Analysis}

\section{Descriptive Statistics}

In this paper, spss19 is used for descriptive statistical analysis of each research variable, and the maximum, minimum, average value and standard deviation of each research variable are calculated, as shown in Table 2.

It can be seen from the table that the average age of managers is 47.51 , indicating that most listed companies in China are generally older than senior executives; The maximum 
educational level is 5, while the average value is 2.48 , which indicates that a small number of managers have higher educational background. Most managers are undergraduates or junior college students. We can infer that managers' educational background does not affect their development very much; The maximum of managers' working time is 16 years, the minimum is 0 or less than one year, and the average is 5.33, which indicates that the tenure of executives in listed companies is longer. The average value of the proportion of managers holding shares is less than 50, it can be explained that the executive is mainly responsible for the daily operation of the company is not the majority shareholder of the company; In terms of the size, liquidity and growth of the control variables, the standard deviation of the three is larger than the mean, which indicates that there may be extreme outliers in the data, which requires further analysis of the data. This paper does not consider its influence on the model for the time being.

Table 2.Descriptive analysis

\begin{tabular}{|l|l|l|l|l|l|}
\hline variable & $\begin{array}{l}\text { Total number } \\
\text { of samples }\end{array}$ & maximum & Minima & $\begin{array}{l}\text { average } \\
\text { value }\end{array}$ & $\begin{array}{l}\text { Standard } \\
\text { deviation }\end{array}$ \\
\hline $\begin{array}{l}\text { Age of managers } \\
\text { (years) }\end{array}$ & 2035 & 65 & 24 & 47.51 & 7.24 \\
\hline Manager education & 2035 & 5 & 0 & 2.48 & 1.91 \\
\hline $\begin{array}{l}\text { Tenure of } \\
\text { managers (years) }\end{array}$ & 2035 & 16 & 0 & 5.33 & 2.62 \\
\hline $\begin{array}{l}\text { managerial } \\
\text { ownership }\end{array}$ & 2035 & 83.35 & 0.00 & 25.77 & 19.86 \\
\hline $\begin{array}{l}\text { Manager's bonus } \\
\text { (Yuan) }\end{array}$ & 2035 & $15,721,400$ & 20,000 & 737239.97 & 1095374.43 \\
\hline company size & 2035 & 0.386 & 7.851 & 3.014 & 0.807 \\
\hline Liquidity & 2035 & 22.95 & 0.023 & 1.87 & 70.02 \\
\hline Growth & 2035 & 3205.01 & -75.58 & 22.69 & 144.83 \\
\hline
\end{tabular}

\section{Correlation Analysis}

This paper analyzes the correlation between the five explanatory variables and the asset-liability ratio, so as to measure their correlation. The results are shown in Table 3.

Table 3. Correlation analysis

\begin{tabular}{|l|l|l|l|l|l|l|l|}
\hline \multicolumn{2}{|c|}{} & $\begin{array}{l}\text { Asset-liability } \\
\text { ratio }\end{array}$ & EB & T00 & $\begin{array}{l}\text { Manager's } \\
\text { bonus }\end{array}$ & $\begin{array}{l}\text { Managerial } \\
\text { ownership }\end{array}$ \\
\hline $\begin{array}{l}\text { Asset-liability } \\
\text { ratio }\end{array}$ & $\begin{array}{l}\text { Pearson } \\
\text { relativity }\end{array}$ & 1 & & & & & \\
\hline Age & $\begin{array}{l}\text { Pearson } \\
\text { relativity }\end{array}$ & -0.008 & 1 & & & & \\
\hline EB & $\begin{array}{l}\text { Pearson } \\
\text { relativity }\end{array}$ & 0.013 & 0.022 & 1 & & & \\
\hline T00 & $\begin{array}{l}\text { Pearson } \\
\text { relativity }\end{array}$ & $0.024^{*}$ & 0.016 & -0.032 & 1 & & \\
\hline $\begin{array}{l}\text { Manager's } \\
\text { bonus }\end{array}$ & $\begin{array}{l}\text { Pearson } \\
\text { relativity }\end{array}$ & $0.086^{* *}$ & 0.000 & 0.023 & 0.055 & 1 & \\
\hline $\begin{array}{l}\text { Managerial } \\
\text { ownership }\end{array}$ & $\begin{array}{l}\text { Pearson } \\
\text { relativity }\end{array}$ & $0.158^{* *}$ & -0.021 & $-0.087^{* *}$ & 0.034 & -0.048 & 1 \\
\hline
\end{tabular}

*. There is a significant correlation between the 0.05 level (bilateral).

**. There was significant correlation at 0.01 level (bilateral).

From the chart, we can see that there is a weak correlation between the age of managers and the asset liability ratio of listed companies, that is, the age and education level of managers are related to managerial entrenchment, but they will not affect the capital structure of listed companies. It is preliminarily assumed that $1 \mathrm{a}, 1 \mathrm{~b}$ is not established. There is a 
significant positive correlation between management term bonus and shareholding ratio and asset liability ratio (capital structure). Managers' term of office, bonus and shareholding ratio are positively correlated with the capital structure of listed companies. The hypothesis $1 \mathrm{C}, 2 \mathrm{a}$ and $2 \mathrm{~b}$ are initially established.

\section{Regression Analysis}

However, from the view of Table 4, the Sig values of managerial age and managerial education are all smaller than $0.1 \mathrm{t}$. It can be inferred that the age of managers and managerial qualifications have no effect on the capital structure of listed companies. Rejected the hypothesis of 1a,1b; The Sig of manager tenure is 0.068 , and the Sig value of manager shareholding ratio and manager bonus is less than 0.05, which indicates that the three are significantly related to capital structure, and get the tenure of manager. The incentive will have a certain impact on the capital structure of the listed company, that is, the two are positively correlated, and the incentive to the manager is inversely proportional to the degree of managerial entrenchment, so assume that $1 \mathrm{c}, 2 \mathrm{a}, 2 \mathrm{~b}$ holds.

Table 4.Model Coefficient Summary

\begin{tabular}{|l|l|l|l|}
\hline & Standardized estimate & $\mathrm{t}$ & Sig \\
\hline constant & & 9.384 & 0.000 \\
\hline Age & -0.005 & -0.158 & 0.887 \\
\hline EB & 0.029 & 0.947 & 0.341 \\
\hline TO & 0.057 & 1.882 & 0.068 \\
\hline EI & 0.163 & 5.281 & 0.000 \\
\hline PI & 0.091 & 3.125 & 0.002 \\
\hline R 2 0.032 & F 8.8728 & sig 0.000 \\
\hline
\end{tabular}

\section{Conclusion and Proposition}

Starting from two aspects of managers' characteristics and managers' incentives, this paper selects five factors to study the relationship between managerial entrenchment and capital structure.

1. The longer the tenure of managers, the greater the control, the higher the degree of defense, the higher the preference for low debt. Therefore, companies should strengthen the flow of talent and strengthen the supervision of the board of directors, and strengthen the internal oversight mechanism. Reducing the dependence of managers on the status of the organization for longer term, thus easing the defense behavior of managers.

2. The degree of equity incentive is negatively related to managerial entrenchment and positively related to the level of debt. Therefore, management can increase the level of ownership, promote the interests of shareholders and managers tend to converge, thereby reducing the behavior of encroaching on the interests of shareholders. And then alleviate the defensive behavior of the management.

3. Performance of managers incentive and managerial entrenchment was negatively correlated, positively correlated with the level of debt. Therefore, in order to ensure more effective implementation of performance incentive, reduce the degree of defense enterprise management so as to enhance the enterprise value, the listed companies should strengthen the incentive in the early strength and ease from the management of defense behavior, to protect the interests of shareholders.

\section{References}

[1]Ayla K. Managerial Entrenchment and the Debt-Equity Choice[J].SSRN working paper,2003(1):120-125 
[2] Novaes W, Zingales . Capital Structure Choice when Managers are in Control: Entrenchment versus Efficiency[J].Working Paper,2003,49(1):49-82

[3] Huang Guoliang, DongFei, FanKe. An empirical Analysis of the impact of Management Defense on Corporate performance: evidence from listed companies in China. [J]. Economic theory and economic management,2010(08)(In Chinese)

[4] Li Bingxiang, YuanYe. The path of influence of manager's management and defense on corporate financing behavior -- Based on the three way interaction analysis framework [J]. modern finance (Journal of Tianjin University of Finance Economics),2016,05:102-113.(In Chinese)

[5] Huang Guoliang, LuoXudong, ShiTingyu, SunJia. Influence of management defense on the capital structure of listed companies. [J]. Business research, 2010,05:53-58(In Chinese)

[6] Jensen C. The modern industrial revolution, exit, and the failure of internal control systems [J]. Journal of Financial, 1993,48(3):831-880

[7] Zweibel J. Dynamic Capital Structure under Managerial Entrenchment [J].American Economic Review,1996 (86):1197-1215.

[8] Eaton J, Rosen H S. Agency. delayed compensation and the structure of executive remuneration [J].Journal of Financer,1983,38(5):1489-1505

[9] M. P. Allen, S. K. Panian. Power, Performance and Succession in the Large Corporat [J].Administrative Science Quarterly,1982,27(4):538-547

[10] I. Friend, L. Lang. An Empirical Test of the Impact of Managerial Serf-interest on Corporate Capital Structure [J].Journal of Finance, 1988(47):271-281 